\title{
„KUTATÁS ÉS KÉPZÉS MA - JOBB EGÉSZSÉG HOLNAP”
}

Talán a stockholmi Karolinska Intézet fentebb idézett jelmondata világítja meg a legjobban annak a területnek a jelentőségét, amelynek áttekintésére Dr. Ralovich Béla legújabb, 2018 májusában megjelent könyvének megírásakor vállalkozott. A Magyar Tudományos Akadémia támogatásával megjelent kötet - a szerző korábban kiadott munkáinak szerves folytatása. A 2011-ben, illetve 2014-ben kiadott I. és II. kötehez hasonlóan Ralovich Béla a magyarországi mikrobiológia müvelésének szervezeti hátteret adó főbb intézmények történetének felvázolásával és az ott korábban végzett, gyakran napjainkra is átnyúló vagy az újonnan felmerült kérdésekre választ kereső alap- és alkalmazott kutatások rövidebb-hoszszabb ismertetésével mutatja be e rendkívül szerteágazó tudományág fejlődését hazánkban.

A 707 oldalas mủ magában foglalja a szöveget illusztráló 240 ábrát, valamint a részekre tagolt Irodalomjegyzéket, a Névmutatót, az Epilógust és az egyes fejezetekkel kapcsolatos dokumentumok másolatait tartalmazó Függeléket is.

Az Elöszóban a szerző elörebocsátotta, hogy müve befejezetlen, és szükségszerủen csak válogatott fejezeteket tartalmaz. A téma bonyolultsága, a terjedelmi és az időbeli korlátok meggátolták abban, hogy munkája valamennyi mikrobiológiai kutatást végző egyetem, főiskola, kutatóhely és laboratórium tevékenységét felölelje, annak ellenére, hogy sokan segítették az egyes fejezetek megalkotásában a határon innen és a határon túlról egyaránt, amint az a Köszönetnyilvánitásból és a fejezeteket követő Megjegyzésekből jól kiolvasható. Ezenkívül számos korábbi, mások által írt fontos összefoglaló munka adatait is felhasználta a szerző; e források egy részét felsorolta a Bevezetésben (I. fejezet), és a kötetben idézett minden lényeges hivatkozás szerepel az Irodalomjegyzékben is.

Néhány alapvető definíció megadását követően (Meghatározások - II. fejezet) rátért az orvostudománnyal kapcsolatos mikrobiológiai kutatások ismertetésére (III. fejezet). Több mint 300 oldalt szentelt az 1850-től szinte napjainkig terjedő, rendkívül szerteágazó kutatási tevékenységek bemutatására. Az 1850 körüli járványügyi helyzetet eredeti dokumentumok másolataival illusztrálta, majd áttekintette a Pesti Királyi Tudományegyetem Orvosi Karának és a kar utódintézményeinek történetét. Külön kiemelte Balogh Kálmán górcsővel (mikroszkóp) végzett vizsgálatait és kísérletes munkáját, valamint iskolaalapító tevékenységét az Általános Kórtani Intézetben, és végigkísérte prominens utódainak munkásságát - a folyton változó szervezeti feltételek között - az Orvosi Mikrobiológiai Intézet kialakulásán át napjainkig. Taglalta a mikrobiológiával kapcsolatos kutatásokat végző további intézetek tevékenységét is, és külön ki- 
tért a hazai szövettenyésztés megindulására és a víruskutatásban betöltött szerepére. Ismertette Semmelweis Ignác munkásságát, annak recepcióját és hatását. A fejezet további erénye, hogy tartalmazza a Kolozsvári Egyetem Orvosi Kara és annak utódai, köztük a Bolyai Tudományegyetem Marosvásárhelyi Orvosi Kara (jelenleg Marosvásárhelyi Orvosi és Gyógyszerészeti Egyetem) történetét és tevékenységét is. Ezután időrendben a Pécsi Tudományegyetem, a Debreceni Egyetem és a Szegedi Tudományegyetem, valamint az Országos Gyógyintézeti Központ (és elődeik) eminens mikrobiológusainak fő kutatási területeit ismerhetjük meg.

Jelentős teret szentelt a szerző a közegészségügyi és közegészséggel kapcsolatos országos intézetek és hatóságok ellenőrző, diagnosztikus és kutatási tevékenységének bemutatására (III.8. alfejezet). Érdemeinek megfelelően hangsúlyosan foglalkozott az Országos Közegészségügyi Intézet (OKI) és hálózata mikrobiológiai diagnosztikában, kutatásban, oktatásban és a betegségmegelözésben betöltött szerepével. A III.9. alfejezetben olvashatók a Magyar Tudományos Akadémia mikrobiológiai profilú kutatóintézeteivel és kutatócsoportjaival, valamint azok előtörténetével összefüggő adatok. Ez egy fontos alfejezet, ám az egyes intézetek munkásságát szemléltető leírások terjedelme és részletgazdagsága változó, ahogyan változó lehetett a szerző rendelkezésére bocsátott vagy az általa felkutatott dokumentumok információtartalma is.

Megfelelőbb hely híján a III.11. alfejezetben írta le az 1945 után a Román Tudományos Akadémia által alapított kutatóintézetek „magyar vonatkozásait”, valamint a marosvásárhelyi Közegészségügyi Intézet (1949-1959) müködését is. Önálló alfejezetet (III.12.) szentelt a honvédségi egészségügyi szolgálat történetének és a valószínűleg csak szük körben ismert, honvédségi szakemberek által végzett mikrobiológiai kutatásoknak.

A III. fejezet zárásaként a szerző egy rövid történeti áttekintésben rekapitulálta a bakteriológiai vizsgálatok hazai kezdeteit. A több mint ötvenoldalas IV. fejezetben került sor az állatorvostudománnyal kapcsolatos mikrobiológiai kutatásokkal összefüggö adatok ismertetésére. Az állatorvosi mikrobiológia kezdetben az orvosi mikrobiológiával szorosan összefonódva alakult ki, majd egyre fontosabb szerepet töltött be a hazai bakteriológia, virológia, mikológia és parazitológia fejlődésében. Az 1850 elötti helyzetet Baranya vármegyének orvosi helyirata (Pécs: 1845) címủ mủ adataival jellemezte. Ezután részletesen taglalta - az állatorvostudomány hazai fejlődését követve - a mai egyetem mikrobiológiát oktató és speciális felkészültséget igénylő mikrobiológiai kutatásokat folytató tanszékeinek, intézeteinek és laboratóriumainak történetét. Bemutatta az állatgyógyászat és azon belül a „közönséges kór- és gyógyszertanítmány és járvány-nyavalya tanítmány” kiemelkedő hazai mestereinek életútját. Külön alfejezetben olvashatók a jelenlegi állategészségügyi rendszer kialakulásával és a munkatársaik által végzett kutatómunkával kapcsolatos adatok. 
Az ugyancsak mintegy ötven oldalt felölelő V. fejezet tárgya Az oltóanyag-kutatás és-termelés hazai története. Ebben a részben Ralovich doktor számba vette, többek között, a himlővírus (poxvirus variolae) okozta egyik legpusztítóbb ragály, a himlő (fekete himlő, variola vera) elleni védekezés kezdeti szakaszát dokumentáló írásokat. Utalt Raymann János Ádám írására, aki 1721-ben szándékosan és eredményesen végezte el saját gyermekei esetében a „karról karra” történő variolációt, a himlőváladék mesterséges átvitelét. Emellett citálta Ralovich doktor az első magyarországi ,,védhimlőoltással” kapcsolatos adatokat is. Ezek szerint a variola vírusnál kevésbé patogén vaccinia vírus által okozott léziókból nyert tehén vagy emberi váladékkal/oltóanyaggal történő mesterséges fertőzést, vagyis az első hazai vakcinációt 1801-ben végezték Sopronban. Ezután indult meg az „óvhimlő oltonyozás” megszervezése, a védőoltással kapcsolatos teendők jogi szabályozása és a megfelelő intézményi keretek megteremtése. Az Egészségügyi Világszervezet (Organisation Mondiale de la Santé; angolul World Health Organization, WHO) 1979-ben jelentette be a himlö eradikációját, ami az egész világra kiterjedő sikeres vakcinációs program eredménye volt. A továbbiakban a szerző ismertette a rabies virus által okozott veszettség elleni okszerü védekezés megszervezésével kapcsolatos adatokat, és rátért a humán- és az állategészségügyi védőoltások hazai elöállításának történetére, felvázolva a magyarországi oltóanyagtermelő intézetek és cégek felvirágzását, majd többségük lehanyatlását. A tudatos védőoltás-politika figyelemre méltó hazai eredményeit a VI. fejezetben összegezte röviden.

A gyógyszerészet, a gyógyszerek és a mikrobiológia kapcsolata címü VII. fejezet a hazai gyógyszergyártás és gyógyszerkutatás történetét taglalja. Ez a fejezet bepillantást nyújt az alap- és alkalmazott kutatásnak egyaránt tekinthető gyógyszerfejlesztés hazai „mühelyeinek” rendkívül magas szintü, kifinomult mikrobiológiai ismereteket igénylő tevékenységébe. Imponáló például a Gyógyszeripari Kutató Intézet szerteágazó projektjeinek leírása. Nyilvánvaló, hogy a termékek előállítását és piacra kerülését intenzív alapkutatás előzte meg, melynek során elvégezték a biológiailag aktív anyagok előállítására alkalmas prokarióta és eukarióta mikroszervezetek élettani vizsgálatát, a legmegfelelőbb törzs kiválasztását, továbbá az optimális ipari szintézist biztosító feltételek pontos meghatározását is. Ezek a kutatások számos magas színvonalú egyetemi doktori, kandidátusi, illetve akadémiai doktori értekezés alapját is képezték. Hasonlóan színvonalas kutató-fejlesztő tevékenység zajlott a gyógyszerkutatással foglalkozó többi egyetemi és ipari központban is. A VIII. fejezetben a szerző a humán egészségügyi, állategészségügyi, ipari és mezőgazdasági laboratóriumokban végzett mikrobiológiai tevékenységekkel kapcsolatos minőségbiztosítás kérdéseivel foglalkozott.

A minőségbiztosítással foglalkozó részt követő Epilógusban (IX. fejezet) Ralovich doktor emléket állított a mikrobiológiai kutatások „,névtelen közkatonáinak”, elismerve tevékenységüket, és kiegészítette a Magyar Mikrobiológiai Társaság 
(MMT) - korábbi mủvében közölt - történeti adatait. Az Epilógust a több egységből álló, 82 oldalas Irodalomjegyzék (X. fejezet) követi, melyben a történeti szempontból jelentős publikációk mellett az egyes kutatási területekkel kapcsolatos reprezentatív tudományos közlemények jegyzéke is megtalálható. A szerző, korrekt módon, nem kívánta értékelni a felsorolt cikkek szakmai jelentőségét. A kötetet Névmutató (XI. fejezet) és az egyes fejezetekhez tartozó dokumentumokat bemutató, csaknem százoldalas Függelék (XII. fejezet) zárja.

Ajánlom ezt a müvet a magyar mikrobiológia fordulatos története iránt édeklödő minden kedves olvasónak.

(Ralovich Béla: Adatok a mikrobiológiával kapcsolatos ismeretek oktatás- és kutatástörténetéhez III. [1850-töl napjainkig]. Balatonberény: magánkiadás, 2018)

Minárovits János az MTA doktora, a Magyar Mikrobiológiai Társaság alelnöke 